\title{
Application of Jatropha curcas L. seed oil (Euphorbiaceae) and microcurrent on the healing of experimental wounds in Wistar rats ${ }^{1}$
}

\author{
Aplicação do óleo das sementes de Jatropha curcas L. (Euphorbiaceae) e microcorrente no \\ reparo de lesões experimentais em ratos Wistar
}

\begin{abstract}
José Roberto Passarini Juniorr, Fernanda Oliveira de Gaspari de Gaspi ${ }^{\mathrm{II}}$, Lia Mara Grosso Neves ${ }^{\mathrm{III}}$, Marcelo Augusto Marreto Esquisatto $^{\mathrm{IV}}$, Gláucia Maria Tech dos Santosv, Fernanda Aparecida Sampaio MendonçavI

IGraduate student, School of Pharmacy, Herminio Ometto University Center, UNIARARAS, Araras-SP, Brazil. Acquisition and interpretation of data, involved in technical procedures.

${ }^{\text {II }} \mathrm{PhD}$, Full Professor, NUCISA, Herminio Ometto University Center, UNIARARAS, Araras-SP, Brazil. Interpretation of data and critical revision. IIIFellow Master degree, Postgraduate Program of Biomedical Sciences, Herminio Ometto University Center, UNIARARAS, Araras-SP, Brazil. Acquisition and interpretation of data, involved in technical procedures.

IvPhD, Full Professor, Postgraduate Program of Biomedical Sciences, Herminio Ometto University Center, UNIARARAS, Araras-SP, Brazil. Acquisition and interpretation of data, histomorphometric analysis.

vPhD, Full Professor, Postgraduate Program of Biomedical Sciences, Herminio Ometto University Center, UNIARARAS, Araras-SP, Brazil. Supervised all phases of the study, manuscript writing and critical revision.

VIPhD, Full Professor, Postgraduate Program of Biomedical Sciences, Herminio Ometto University Center, UNIARARAS, Araras-SP, Brazil. Main author. Tutor, responsible for conception, design, intellectual and scientific content of the study; critical analysis; final approval of manuscript.
\end{abstract}

\section{ABSTRACT}

PURPOSE: To investigate the effects of Jatropha curcas L. seed oil and microcurrent stimulation on the healing of wounds experimentally induced in Wistar rats.

METHODS: Forty-eight animals were divided into four groups: (A) control; (B) treated with microcurrent (10 $\mu \mathrm{A} / 2 \mathrm{~min})$; (C) treated with $J$. curcas seed oil, and (D) treated with $J$. curcas seed oil plus microcurrent. Tissues samples were obtained two, six, ten and 14 days after injury and submitted to structural and morphometric analyses.

RESULTS: The animals of groups A and C showed similar responses in terms of repair area, total number of cells, number of newly formed blood vessels, epithelial thickness, and percentage of area occupied by mature collagen fibers. Significant differences in all parameters analyzed were observed between animals of groups B and D and the control 10 and 14 days after experimentally induced injury. The morphometric data confirmed the structural findings

CONCLUSIONS: The application of J. curcas seed oil alone was not effective on experimental wound healing when compared to control, but microcurrent application alone or combined with the oil exerted significant differences in the parameters studied. These findings suggest that the positive results were due to microcurrent stimulation.

Key words: Jatropha curcas. Wound Healing. Histology, Comparative. Rats.

\section{RESUMO}

OBJETIVO: Investigar os efeitos do óleo das sementes de Jatropha curcas L.e microcorrente em lesões experimentais em de ratos Wistar.

MÉTODOS: Quarenta e oito animais foram divididos em quatro grupos: (A) controle, (B) tratado com aplicação de microcorrente, (C) tratado com óleo de sementes de $J$. curcas e (D) tratado com de óleo de sementes de $J$. curcas associado à microcorrente. Amostras de tecido foram obtidas no $2^{\circ}, 6^{\circ}, 10^{\circ}$ e $14^{\circ}$ dia após a lesão e submetidas às análises estrutural e morfométrica.

RESULTADOS: Os animais dos grupos A e C apresentaram respostas semelhantes quanto a seus efeitos sobre as medidas da área de reparo, número total de células e de vasos sanguíneos neoformados, espessura do epitélio e porcentagem da área ocupada por fibras colágenas maduras. Os grupos de animais B e D apresentaram resultados diferenciados e significativos em todos os parâmetros analisados nos dez e 14 dias após a lesão experimental. Os dados morfométricos confirmaram os achados estruturais.

CONCLUSÕES: A aplicação do óleo das sementes de J. curcas não promoveu respostas significativas no reparo das lesões experimentais quando comparadas ao controle, mas a microcorrente aplicada isolada ou combinada a este óleo apresentou diferenças significativos nos parâmetros estudados Este fato sugere que os resultados positivos se devem provavelmente a ação da aplicação da microcorrente Descritores: Jatropha curcas. Cicatrização. Histologia Comparada. Ratos. 


\section{Introduction}

Popular observation of the use and efficacy of medicinal plants in wound healing has contributed significantly to the study of their properties and therapeutic effects. In this respect, folk medicine raises the interest of researchers in studies that involve multidisciplinary areas ${ }^{1}$. Medicinal plants are important for pharmacological research and for the development of novel drugs. In the latter case, the plant or its constituents can be used directly as the therapeutic agent, but also as a starting material for the synthesis of drugs or as a model of pharmacologically active compounds. Phytopharmaceutical laboratories concentrate their efforts on identifying the active substances and mechanisms of different plants. The medicinal value of these plants lies in their phytochemical constituents that belong to different chemical families, such as alkaloids, essential oils, flavonoids, tannins, terpenoids, saponins, and phenolic compounds ${ }^{2-4}$.

Jatropha curcas L. (family Euphorbiaceae), known as "pinhão manso" (physic nut), is native to tropical countries and can be cultivated in areas with poorly fertile soils and unfavorable climate. These characteristics make the plant a promising biofuel ${ }^{5,6}$. Although the oil has a high energy content, other components of this plant may also be used as an energy source ${ }^{7,8}$. However, this plant is not only economically and environmentally important as a source of biodiesel, but is also used as a folk remedy in many countries for the treatment of various diseases. All parts of the plant can be used for a variety of purposes. The latex derived from $J$. curcas has medicinal, pesticidal and antimicrobial properties and is widely used as a healing agent ${ }^{9}$. Villegas et al. ${ }^{10}$, studying the wound healing activity of the latex in rats, found that this property is due to the presence of a proteolytic enzyme. The roots, stems, bark, leaves, seeds and fruits, fresh or cooked, are widely used in traditional folk medicine in many parts of Western Africa ${ }^{11,12}$. Esimone et al. ${ }^{13}$ obtained promising results with an ointment containing fresh $J$. curcas leaf extract applied to excision wounds created in the back skin of albino rats. In a study using albino mice, Shetty et al. ${ }^{14}$ showed that crude J. curcas bark extract was effective in accelerating the healing process of experimentally induced skin wounds. Direct application of crushed leaves of the plant to cuts and wounds has been shown to promote coagulation. The seeds of $J$. curcas are used as anthelminthic agent and for the treatment of gout, paralysis, ascites, and skin disease. The seed oil of the plant has been to shown to be effective in treating rheumatic diseases, parasitic skin diseases, itching, jaundice and fever, as well as a diuretic agent ${ }^{14-17}$.

The wound healing process is a well-organized chain of biochemical and cellular events that promote platelet aggregation, activation of the coagulation cascade, inflammatory infiltration, cell differentiation, and tissue remodeling. This process involves the activity of an intricate network of blood cells, cytokines, and growth factors that restore the normal condition of skin or tissue ${ }^{18}$. Clinical evidence indicates that the repair of dermal and subdermal connective tissue can be accelerated by the external application of a low-intensity electrical current. Electrical stimulation using lowintensity (microamperage) currents is compatible with endogenous currents that act in the organism at the cellular level, accelerating wound healing and improving the quality of scar tissue ${ }^{19}$. Studies investigating the effects of electrical current stimulation using different amplitudes and frequencies have shown that these procedures promote cellular modifications and tissue responses in experimentally induced wounds ${ }^{20-22}$. Mendonça et al. ${ }^{23}$ investigated the effect of microcurrent stimulation $(10 \mu \mathrm{A})$ on wound healing in rats and observed that this treatment is effective in promoting tissue repair, exerting positive effects on the newly formed tissue area, number of fibroblasts, number of newly formed vessels, and epithelial thickness.

The objective of the present study was to investigate the effects of Jatropha curcas L. seed oil and microcurrent stimulation on the healing of wounds surgically induced in the back skin of Wistar rats.

\section{Methods}

Forty-eight male Wistar rats (Rattus norvegicus), 120 days old and weighing on average $250 \mathrm{~g}$, obtained from the Center of Animal Experimentation, Herminio Ometto University Center, UNIARARAS, were used. The animals were maintained in individual cages at a constant temperature of $23 \pm 2^{\circ} \mathrm{C}$ under a 12-h light/dark cycle, and received commercial chow and water ad libitum. No differences in behavior were observed between animals during the study. The experimental procedures were approved by the Ethics Committee of Herminio Ometto University Center (protocol 058/2011) and were conducted in accordance with international regulations on animal testing and biodiversity ${ }^{24,25}$.

\section{Preparation of the extract}

The seeds of Jatropha curcas L. (Euphorbiaceae) were selected, broken down into smaller pieces on dry ice, and ground with a knife mill. The material was then extracted with hexane in an extractor tank under pneumatic agitation for $1 \mathrm{~h}$. The procedure was repeated three times and the solvent was changed between extraction runs. The extracted material was concentrated by rotary 
evaporation until only the oil was left.

\section{Experimental model}

A trichotomy was performed $48 \mathrm{~h}$ before surgical intervention. After local asepsis, the animals were anesthetized with xylazine hydrochloride (20 mg/kg body weight) and ketamine hydrochloride (50 mg/kg). The site of incision was measured with a caliper in the craniocaudal direction ( $2 \mathrm{~cm}$ long and $2 \mathrm{~mm}$ deep) and was marked with a ballpoint pen. The incision was then made in the back skin of the animal and was left unsutured.

The animals were divided into four groups of 12 animals each: group A, control; group B, treated with microcurrent (10 $\mu \mathrm{A} / 2 \mathrm{~min} /$ day); group $\mathrm{C}$, treated with $J$. curcas seed oil; group D, treated with $J$. curcas seed oil and microcurrent (10 $\mu \mathrm{A} / 2 \mathrm{~min} /$ day). Treatments were performed according to the protocol of Mendonça et $a .^{23}$.

Collection and preparation of samples for structural analysis

Three animals from each group were sacrificed with an overdose of the anesthetic at two, six, ten and 14 days after experimentally induced injury. The total wound area (120 to $160 \mathrm{~mm}^{2}$ ) was removed for structural and morphometric analyses. Each sample was removed and fixed in 10\% formalin in Millonig buffer, $\mathrm{pH} 7.4$, for $24 \mathrm{~h}$ at room temperature. Next, the specimens were washed in the buffer solution and processed for embedding in Paraplast ${ }^{\circledR}$. Longitudinal sections $(7 \mu \mathrm{m})$ were stained with hematoxylin-eosin for routine histology and with picrosirius-hematoxylin for the observation of collagen fibers. The specimens were examined and documented under a Leica DM 2000 photomicroscope at the Laboratory of Micromorphology, Herminio Ometto University Center, UNIARARAS.

\section{Morphometric analysis}

Images from cross-sections of the mid-region of the experimental wound were captured and digitized using a Leica DM 2000 photomicroscope. Digitized images were used for the determination of the morphometric parameters: tissue repair area $\left(\mu \mathrm{m}^{2}\right)$, total number of cells (fibroblasts and inflammatory

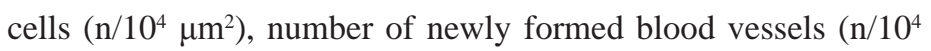
$\mu \mathrm{m}^{2}$ ), and thickness of regenerated epithelium $(\mu \mathrm{m})$. For this analysis, three specimens were randomly selected among the sections obtained. For this purpose, three samples of $10^{4} \mu \mathrm{m}^{2}$, using virtual Leica Image Measure ${ }^{\mathrm{TM}}$ grid, were collected from central region of experimental lesion in each animal. To measure the area of granulation tissue deposition in repair area was used tool contouring program from Sigma Scan Pro 6.0 ${ }^{\mathrm{TM}}$ in the same sections cited above. The results were entered into spreadsheets (Biostat for Windows XP program) and compared by ANOVA and the Tukey post-hoc test. A level of significance of $5 \%$ was adopted $^{26}$.

\section{Results}

Tissue repair was studied in the different groups by comparing inflammatory and proliferative processes and tissue reorganization. For this purpose, samples were collected from the wound area two, six, ten and 14 days after experimentally induced injury. Temporal differences in tissue repair were observed between the different treatments.

All samples obtained from control animals (group A) and animals treated with the $J$. curcas seed oil (group C) were similar in terms of the parameters studied. In these groups, the inflammatory phase was already established by day 2 after injury and the structural features of the proliferative and remodeling phases were observed between day 6 and day 14 (Figure 1). Differences were observed for animals submitted to microcurrent stimulation (group B) and microcurrent stimulation plus J. curcas seed oil (group D). These animals presented an increase in the total number of cells in the wound area by day 6 when compared to groups A and C. On day 10, this area was already reepithelialized and the collagen fibers were compacted and reorganized.

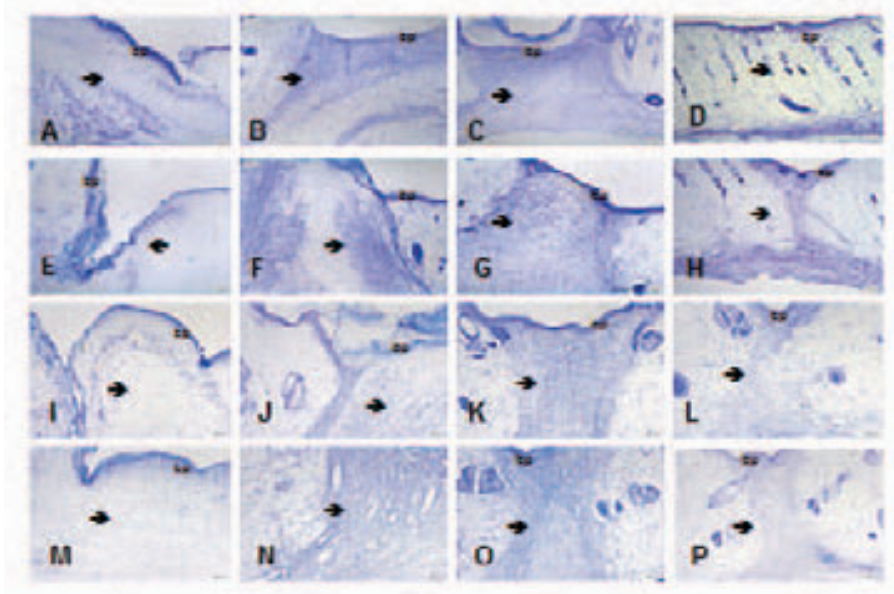

FIGURE 1 - Photomicrographs of cross-sections of wounds experimentally induced in Wistar rats. Group A, control (A-D); group B treated with microcurrent $(10 \mu \mathrm{A} / 2 \mathrm{~min} /$ day $)(\mathbf{E}-\mathbf{H})$; group $C$ treated with Jatropha curcas seed oil (I-L), and group D treated with Jatropha curcas seed oil and microcurrent $(10 \mu \mathrm{A} / 2 \mathrm{~min} /$ day $)$ (M-P). Tissue samples were collected on day 2 (A, E, I and $\mathbf{M}$ ), day 6 (B, F, J and $\mathbf{N}$ ), day 10 (C, G, K and $\mathbf{O}$ ), and day 14 (D, H, $\mathbf{L}$ and $\mathbf{P}$ ) after injury. The sections were stained with Toluidine blue. (Ep) Epithelium; $(\rightarrow)$ repair area in the dermis. Bar $=100 \mu \mathrm{m}$. 
Tissue repair was significantly higher in groups B and D between day 6 and day 10 when compared to groups A and C, but remained stable between days 10 and 14 in all groups (Figure 2). An expressive increase in the total number of cells in the repair area was observed between days 2 and 6 after surgically induced injury in all groups. However, this number was higher in groups $\mathrm{B}$ and D after 10 and 14 days of treatment (Figure 3). These same parameters were seen for the formation of newly formed blood vessels, with the observation of significantly larger numbers in groups B and D (Figure 4). Reorganization of the wound area was similar in the different groups (Figures 1 and 5).

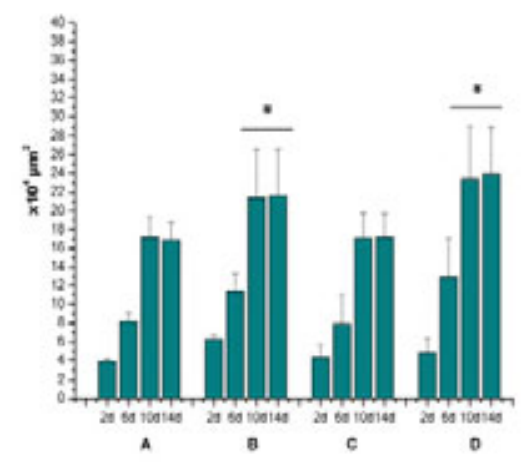

FIGURE 2 - Size of the tissue repair area $\left(\mathrm{x} 10^{4} \mu \mathrm{m}^{2}\right)$ in wounds experimentally induced in Wistar rats. Group A, control; group B treated with microcurrent (10 $\mu \mathrm{A} / 2 \mathrm{~min} /$ day); group C treated with Jatropha curcas seed oil, and group D treated with Jatropha curcas seed oil and microcurrent (10 $\mu \mathrm{A} / 2 \mathrm{~min} /$ day). Tissue samples were collected on day 2 (2d), 6 (6d), 10 (10d), and 14 (14d) after injury. Results are reported as the mean and standard deviation of each group and were compared by ANOVA and Tukey's post-hoc test $(\mathrm{p}<0.05)$. The asterisk indicates significant differences between time points.

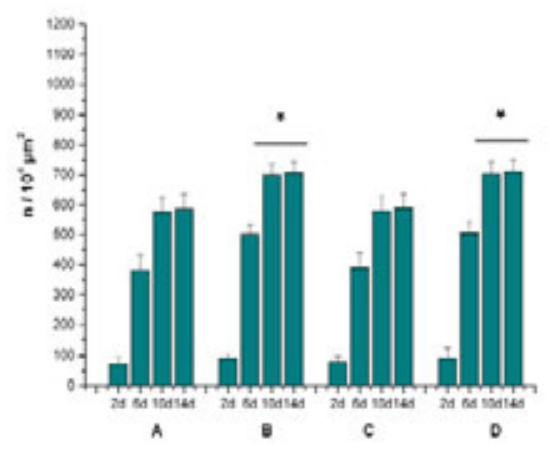

FIGURE 3 - Total number of cells $\left(\mathrm{n} / 10^{4} \mu \mathrm{m}^{2}\right)$ in wounds experimentally induced in Wistar rats. Group A, control; group B treated with microcurrent $(10 \mu \mathrm{A} / 2 \mathrm{~min} /$ day); group $\mathrm{C}$ treated with Jatropha curcas seed oil, and group D treated with Jatropha curcas seed oil and microcurrent $(10 \mu \mathrm{A} / 2$ min/day). Tissue samples were collected on day 2 (2d), 6 (6d), 10 (10d), and 14 (14d) after injury. Results are reported as the mean and standard deviation of each group and were compared by ANOVA and Tukey's posthoc test $(\mathrm{p}<0.05)$. The asterisk indicates significant differences between time points.

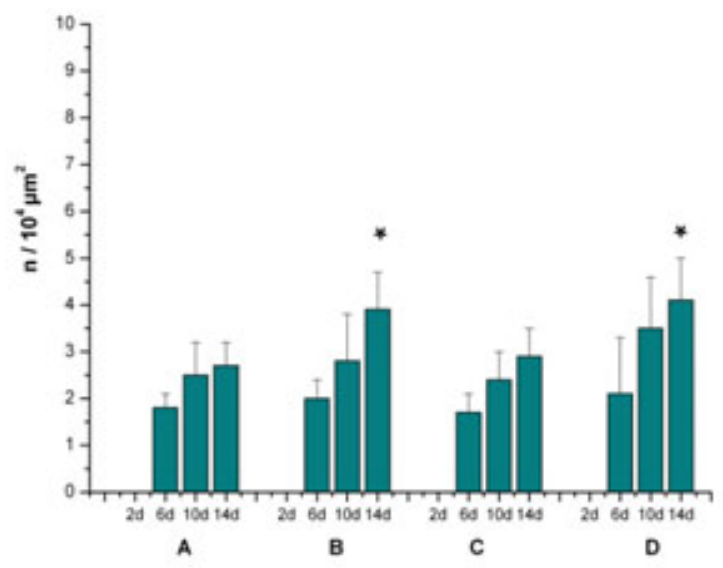

FIGURE 4 - Number of newly formed blood vessels $\left(n / 10^{4} \mu m^{2}\right)$ in wounds experimentally induced in Wistar rats. Group A, control; group B treated with microcurrent $(10 \mu \mathrm{A} / 2 \mathrm{~min} /$ day $)$; group $\mathrm{C}$ treated with Jatropha curcas seed oil, and group D treated with Jatropha curcas seed oil and microcurrent $(10 \mu \mathrm{A} / 2 \mathrm{~min} /$ day $)$. Tissue samples were collected on day 2 (2d), 6 (6d), 10 (10d), and 14 (14d) after injury. Results are reported as the mean and standard deviation of each group and were compared by ANOVA and Tukey's post-hoc test $(\mathrm{p}<0.05)$. The asterisk indicates significant differences between time points.

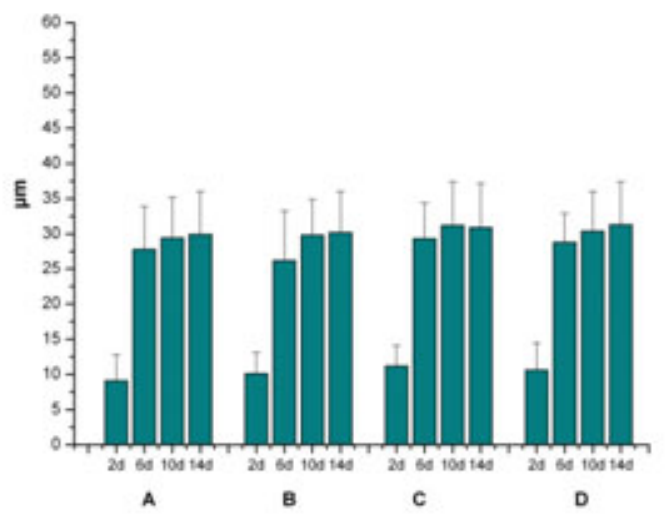

FIGURE 5 - Epithelial thickness $(\mu \mathrm{m})$ in wounds experimentally induced in Wistar rats. Group A, control; group B treated with microcurrent (10 $\mu \mathrm{A} / 2 \mathrm{~min} /$ day); group $\mathrm{C}$ treated with Jatropha curcas seed oil, and group D treated with Jatropha curcas seed oil and microcurrent $(10 \mu \mathrm{A} / 2 \mathrm{~min} /$ day). Tissue samples were collected on day 2 (2d), 6 (6d), 10 (10d), and 14 (14d) after injury. Results are reported as the mean and standard deviation of each group and were compared by ANOVA and Tukey's post-hoc test $(p<0.05)$. No significant differences were observed between time points. 


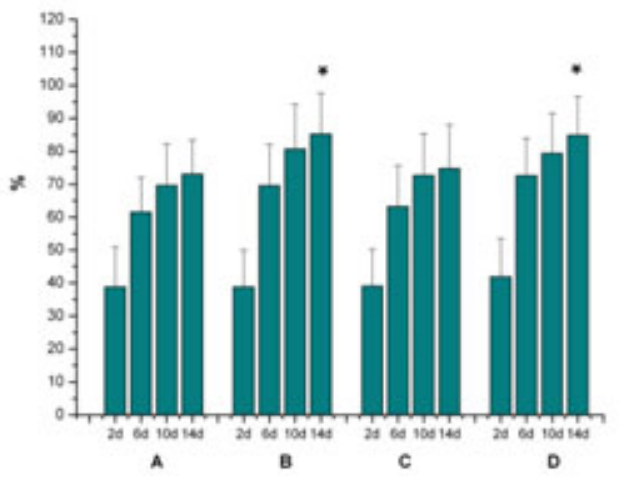

FIGURE 6 - Percent area occupied by mature collagen fibers in relation to total repair area in wounds experimentally induced in Wistar rats. Group A, control; group B treated with microcurrent $(10 \mu \mathrm{A} / 2 \mathrm{~min} /$ day $)$; group $\mathrm{C}$ treated with Jatropha curcas seed oil, and group D treated with Jatropha curcas seed oil and microcurrent $(10 \mu \mathrm{A} / 2 \mathrm{~min} /$ day $)$. Tissue samples were collected on day 2 (2d), 6 (6d), 10 (10d), and 14 (14d) after injury. Results are reported as the mean and standard deviation of each group and were compared by ANOVA and Tukey's post-hoc test $(\mathrm{p}<0.05)$. The asterisk indicates significant differences between time points.

Analysis of the dermal extracellular matrix showed intense deposition of collagen fibers in all groups in the first days after experimentally induced injury. Marked fiber remodeling and an increase in the degree of fiber compaction were observed between days 10 and 14 . In all groups, this remodeling of new fibers first became evident at the periphery of the wound area and then extended into the center of the newly formed tissue (Figure $1)$. These data were confirmed by differences in the area occupied by birefringent fibers in relation to the total repair area (Figure 6), with animals of groups B and D presenting significantly higher values than those of groups $\mathrm{A}$ and $\mathrm{C}$.

No elastic system fibers were detected in the repair area until day 10 of treatment in any of the groups. However, elastic fibers were seen close to the epidermis on day 14 after experimentally induced injury (Figure 1).

\section{Discussion}

In the present study, application of Jatropha curcas L. seed oil alone had no beneficial effects on the healing time of wounds experimentally induced in Wistar rats. However, significant effects were observed when the oil was applied simultaneously with microcurrent stimulation. In this respect, microcurrent application alone or in combination with the seed oil promoted an increase in the total number of cells, number of newly formed blood vessels, epithelial thickness, and compaction of mature collagen fibers in the wound area of animals on days 10 and 14 after experimentally induced injury.

In a phytochemical study of ethanolic leaf extract of $J$. curcas, Ebuehi and Okorie ${ }^{27}$ detected the presence of alkaloids, cardiac and cyanogenic glycosides, tannins, flavonoids, and saponins. Tannins and flavonoids are known to be angiogenic and to block necrosis ${ }^{28}$. The antioxidant properties of phytotherapeutic agents have been suggested to be related to the presence of compounds such as tannins, flavonoids, isoflavones, and other phenolic compounds ${ }^{29,30}$.

Analysis of the composition of J. curcas oil showed the presence of $42 \%$ oleic acid, $35 \%$ linoleic acid, 14\% palmitic acid, and $6 \%$ stearic acid $^{31}$, compounds also conferring antioxidant properties to this oil. In vitro studies have demonstrated the efficacy of conjugated linoleic acid in reducing free radicals peroxidants ${ }^{32,33}$. The antioxidant activity of this acid is comparable to that of synthetic antioxidants ${ }^{34-36}$. In a phytochemical study of different parts of $J$. curcas, Nwokocha et al. ${ }^{37}$ detected phenolic compounds such as tannins, flavonoids, alkaloids and saponins in the leaves, stem and seeds of this plant. Numerous studies have investigated the effect of plant extracts with antioxidant properties on tissue healing ${ }^{23,38-40}$.

Although antioxidant compounds have been identified in the seed oil of J. curcas, in the present study application of the oil alone was not effective in accelerating wound healing in treated animals. On the other hand, microcurrent application to the wound area elicited positive responses, including an increase in the repair area, total number of cells, number of newly formed blood vessels, and percentage of mature collagen fibers at the site of injury ${ }^{19,41-43}$. According to Mendonça et al. ${ }^{23}$, microcurrent application to wounds might be used as a coadjuvant to accelerate the healing process, increasing fibroblast proliferation, angiogenesis, and collagen deposition at the site of injury.

Similar effects were observed when microcurrent and $J$. curcas seed oil were applied simultaneously to the wounds. These findings agree with experimental studies combining microcurrent stimulation and plant extracts ${ }^{23,39,40}$. However, analysis of the findings indicates that the positive effects of this combination were the result of microcurrent stimulation and not of the J. curcas seed oil since the latter alone did not promote significant wound healing in treated animals. Therefore, the efficacy of the seed oil in wound healing does not seem to be the same as that reported for the crude leaf extract of this plant ${ }^{13}$, probably because different parts of $J$. curcas contain different concentrations of antioxidant compounds. According to the phytochemical analysis conducted by Nwokocha et $a .^{37}$, the concentration of tannins, flavonoids, saponins, and phenols is much lower in the seeds of this species 
compared to its leaves.

\section{Conclusion}

The J. curcas seed oil alone was not effective in promoting the healing of wounds experimentally induced in the back skin of Wistar rats, whereas microcurrent application alone or combined with the oil exerted significant effects on the different parameters studied when compared to the control group.

\section{References}

1. Maciel MAM, Pinto AC, Veiga Jr. Plantas medicinais: a necessidade de estudos multidisciplinares. Química Nova. 2002;25(3):429-38.

2. Nayak BS, Pinto Pereira LM. Catharanthus roseus flower extract has wound-healing an in Sprague Dawley rats. BMC Complement Alter Med. 2006;6:41.

3. Edeoga HO, Okwu DE, Mbaebie BO. Phytochemical constituents of some Nigerian medicinal plants. Afr J Biotechnol. 2005;4(7):685-8.

4. Thakur R, Jain N, Pathak R, Sandhu SS. Practices in wound healing studies of plants. Evid Based Complement Alternat Med. 2011;2011:438056.

5. Openshawk K. A review of Jatropha curcas: an oil plant of unfulfilled promise. Biomass Bioenergy. 2000;19(1):1-15.

6. Arruda F, Beltrão NEM, Andrade AP, Pereira WE, Severino LS. Cultivo de pinhão-manso (Jatropha curcas L.) como alternativa para o semi-árido nordestino. R Bras Oleag Fibrosas. 2004;8:789-99.

7. Gübitz GM, Mittelbach M, Trabi M. Exploitation of the tropical oil seed plant Jatropha curcas L. Bior Tech. 1999;67:73-82.

8. Augustus GDPS, Jayabalan M, Seiler GJ. Evaluation and bioinduction of energy components of Jatropha curcas. Biomass Bioenergy. 2002;23(3):161-4.

9. van den Berg AJ, Horsten SF, Kettenes-van den Bosch JJ, Kroes BH, Beukelman CJ, Leeflang BR, Labadie RP. Curcacycline A--a novel cyclic octapeptide isolated from the latex of Jatropha curcas L. FEBS Lett. 1995;358( 3):215-8.

10. Villegas LF, Fernandez ID, Maldonado H, Torres R, Zavaleta A, Vaisberg AJ, Hammond GB. Evaluation of the wound-healing activity of selected traditional medicinal plants from Peru. J Ethnopharmacol. 1997;55:193-200.

11. Hikwa D. Jatropha curcas L. Agronomy Research Institute, Department of Research and Secialist Services (DR and SS), Harare, Zimbabwe. 1995:1-4.

12. Makkar HPS, Becker K, Sporer F, Wink M. Studies on nutritive potential and toxic constituents of different provenances of Jatropha curcas. J Agric Food Chem. 1997;45:3152-7.

13. Esimone CO, Nworu CS, Jackson CL. Cutaneous wound healing activity of a ointment containing the leaf extract of Jatropha curcas L. (Euphorbiaceae). Int J App Res in Nat Prod. 2009;1(4):1-4.

14. Shetty S, Udupa SL, Udupa AL, Vollala VR. Wound healing activities of bark extract of Jatropha curcas Linn in albino rats. Saudi Med. J. 2006;21(10):1473-6.

15. Adam SEI. Toxic effects of Jatropha curcas in mice. Toxicology.1974;2(1):67-76.

16. Ahmed OMN, Adam SEI. Effects of Jatropha curcas on calves. Vet Pathol. 1979;16(4):476-82.

17. Abdu-Aguye I, Sannusi A, Alafiya RA, Bhusnurmath SR. Acute toxicity studies with Jatropha curcas L. Hum Tox. 1986;4:269-74.
18. Clark RAF. Cutaneous wound repairs. In: Goldsmith LA (ED) Physio, Biochem and Mol Biology Skin. New York: Oxford University Press. 1991:576.

19. Kloth LC, Electrical stimulation for wound healing: a review of evidence from in vitro studies, animal experiment, and clinical trials. Int J Low Exterm Wounds. 2005;4(1):23-44.

20. Becker R, Selden G. The Body Electric. New York: William Morrow and Co. 1985.

21. Basset CA. Beneficial effects of electromagnetic fields. J Cell Biochem. 1993;51:387-93.

22. Bayat M, Asgari-Moghadam Z, Maroufi M, Rezaie FS, Rakhshan M. Experimental wound healing using microamperage electrical stimulation in rabbits. J Rehabil Res Dev. 2006;43(2):219-26.

23. Mendonça FAS, Passarini Jr JR, Esquisatto MAM, Mendonça JS, Franchini CC, Santos GMT. Effects of the application of Aloe vera (L.) and microcurrent on the healing of wounds surgically induced in Wistar rats (Rattus norvegicus). Acta Cir Bras. 2009;24:150-5.

24. Cioms. International Guiding Principles for Biomedical Research Involving Animals. 1985.

25. NIH. Guide for the Care and Use of Laboratory Animals. 1996.

26. Miller RG. Simultaneous Statistical Inference. 2 ed. New York, NY: Springer Verlag; 1981.

27. Ebuehi OA, Okorie NA. Phytochemical screening and quantification of flavonoids from leaf extract of Jatropha curcas Linn. Nig Q J Hosp Med. 2009;19(4):200-5.

28. Suntar IS, Koca U, Akkol K, Yilmazer D, Alper M. Assessment of wound healing activity of aqueous extracts of Colutea cilicia Boiss.\& Bal. fruits and leaves BMC Compl Alt Med. 2011;2011:17.

29. Kahkonen MP, Hopia AI, Vuorela HJ, Rauha JP, Pihlaja K, Kujala TS, Heinonen M. Antioxidant activity of plant extracts containing phenolics compounds. Agric Food Chem. 1999;47(10):3954-62.

30. Addison L, Goody JS, Ferrier LAM, Stedman JR, Brandi MGL. Proparacaine e caracterização de extrato glicólicos enriquecidos em taninos a partir das cascas de Stryphnodendron adstrinens (Mart.) Coville (Barbatimão). Rev Bras Farmacol. 2002;12:7-34

31. Carlsson AS. Plant oils as feedstock alternatives to petroleum - A short survey of potential oil crop platforms. Biochimie. 2009;91:66570 .

32. Banni S, Martin JC. Conjugated linoleic acid and metabolites. Sebedio JL e Christie WW. eds. Trans Fatty Acids in Human Nutrition 1998:261-302 Oily Press Aberdeen, UK.

33. Yu L. Free radical scavenging properties of conjugate linoleic acid. J Agric Food Chem. 2001;49:3452-6.

34. O’Quinn, PR, Nelssen JL, Goodband RD, Tokach MD. Conjugated linoleic acid Anim Health Res Rev. 2000;1:35-46.

35. Kelly GS. Conjugated linoleic acid. Alter Med Rev. 2001;6:367-82.

36. Devery R, Miller A, Stanton C. Conjugated linoleic acid and oxidative behavior in cancer cells. Biochem Soc Trans. 2001;29:3414.

37. Nwokocha A, Blessing IO, Agbaqwa, Okoli BE. Comparative phytochemical screening of Jatropha L. species in the Niger Delta. Res J Phytochem. 2011;5(2):107-14.

38. Sanhueza JC, Nieto SK, Valenzuela AB. Acido linoleico conjugado: un acido graso con isomeria trans potencialmente benefisioso. Rev Chil Nutr. 2002;29(2):98-105.

39. de Gaspi FOG, Foglio MA, Carvalho JE, Santos GMT, Testa Milena, Passarini Jr JR, Moraes CP, Esquisatto MAM, Mendonça JS, Mendonça FAS. Effects of the topical application of hydroalcoholic leaf extract of Oncidium flexuosum Sims. (Orchidaceae) and microcurrent on the healing of wounds surgically induced in Wistar rats. Evid Based Complement Alternat Med. 2011;2011:1-9.

40. Migliato KF, Chiosini MA, Mendonça FAS, Esquisatto MAM, 
Salgado HR, Santos GMT. Effect of glycolic extract of Dillenea indica L. combined with microcurrent stimulation on experimental lesions in Wistar rats. Wounds. 2011;23(5):111-20.

41. Macedo ABC, Simões ND. Aplicação de estimulação elétrica de baixa intensidade no tratamento de úlceras varicosas. Phys Ther Movement. 2007;20:25-33.

42. Lee BY, Al-Waili N, Stubbs D. Ultra-low microcurrent in the management of diabetes mellitus, hypertension and chronic wounds: report of twelve case and discussion of mechanism of action. Int J Med Sci. 2010;7:29-35

43. Santos VNS, Ferreira LM, Horibe EK, Duarte IS. Electric microcurrent in the restoration of the skin undergone a trichloroacetic acid peeling in rats. Acta Cir Bras. 2004;19:466-9.

\section{Acknowledgment}

Thanks to Herminio Ometto Fundation, University

\section{Correspondence:}

Fernanda Aparecida Sampaio Mendonça

UNIARARAS - Centro Universitário Hermínio Ometto

Av. Maximiliano Barutto, 500

13.607-339 Araras - SP Brasil

Tel.: (55 19)3543-1474

fernandamendonca@uniararas.br

Received: February 15, 2012

Review: April 12, 2012

Accepted: May 14, 2012

Conflict of interest: none

Financial source: PROPESQ/UNIARARAS

${ }^{1}$ Research performed at Center for Animal Experimentation and Laboratory of Micromorphology, Herminio Ometto University Center, Araras University (UNIARARAS), Sao Paulo, Brazil. 